\title{
Goal Post Safety - A Case Problem
}

\author{
Ben Neil, Esq., Former President of Maryland State Youth Soccer Association, Maryland, USA
}

\begin{abstract}
This case will provide an excellent test for a student's basic knowledge of tort actions and various defenses which may be used. The case introduces students to the growing problem of goal post safety. It also highlights the need for more information regarding the use of portable goals.

This case is suited to students who need to understand tort actions, its possible defenses and finally soccer goal post safety issues... After reading and discussing the case, students should have a pragmatic understanding of tort actions, their possible defenses and a rationale as to security issues involving movable soccer goal posts.

With more than 500,000 soccer goals in the United States, the majority made of metal and weighing $150-500$ pounds, and with additional goals in the United Kingdom, Ireland and Japan, the potential for catastrophic injuries keeps increasing.
\end{abstract}

Keywords: Soccer; Goal Post; Injuries; Liability

\section{INTRODUCTION}

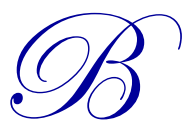

illy was an active six year old boy, who had just started playing soccer. He was not very interested in playing but his father had recommended that he play as a form of exercise. On the first day of team practice, no one wanted to play the position of team goalkeeper. So, Billy was selected by the team coach, who was also a team parent and volunteer, to fill that role. The league is organized and run by the New Windsor Recreation Council, which is a 501 c (3) non-profit organization.

As part of their program administration, the recreation council purchased twenty sets of portable steel soccer goals from "Goal First Inc.", a British manufacturing company that sells items on-line in the United States and elsewhere around the world. As part of the packaging, the company always includes instructions for proper assembly and instructions on the proper method of anchoring the goals. Depending on the types of soil, the amount of moisture and the weight of the goals themselves. Allowing for the following methods to secure the goals in question: auger style, semi-permanent, peg or stake style, J-hook shaped stake, sandbags, counterweights and finally net pegs.

All of the soccer fields that are used by the recreation council are either owned or operated by the County government.

During a break in the practice, Billy apparently decided to jump up, grab the top bar and swing back and forth. Billy's mother, who witnessed the accident, told investigators that she yelled for her son to get off, just before it fell on him. As a result of his swinging, the goal posts became unstable, as it was not securely anchored, and it fell forward, when the 18 foot wide, $6 \frac{1}{2}$ foot high goal, fell on his head and neck, fracturing his skull. After he was freed from beneath the goal, he was immediately taken to the nearby hospital where he was pronounced dead due to head trauma.

It is generally unknown that there are thousands of deadly, unsecured soccer goals all over the country. And movable goals, such as this one, can very easily tip over and fall, thereby causing serious injuries and even death. As in this case, most accidents do not occur during a game, but when children use them as a jungle gym or monkey bars. Children do not consider the potential harm. And the thrill of climbing and playing will generally overcome any warnings or admonitions from adults. 
The only known method of keeping movable goals from tipping over is to secure them by one of the methods previously listed. However, goals are all too often not attached securely or are not re-secured after they have been moved.

Billy's parents brought tort actions against multiple and various defendants as a result of this tragic death. They included the New Windsor Recreational Council, the County Government, the goal manufacturer, the volunteer coach and the Board of Directors for the recreational council.

The complaint alleges that each and every defendant knew or should have known of the inherent dangers of unsecured movable goals. And thereby failed in their duty to warn or protect individuals such as Billy.

\section{TEACHING NOTES}

\section{Questions}

1. Does it make a difference as to which State this accident occurred?

Yes. 46 States follow the concept of "comparative" negligence statutes. While the remaining States follow "contributory" negligence.

In a contributory negligence state, you cannot collect any money, if the fact finder (judge or jury) determines that your actions contributed in any way to your injuries. As an example, the contributory negligence standard was adopted in Maryland in 1847 in the case of Irwin vs. Spriggs. Since then, Maryland has followed that ruling for the past 168 years. Reasoning that any changes need to come from the legislature and not the Courts.

Ensured, a plaintiff who is found to be contributory negligent will receive zero dollars as compensation.

On the other hand, in a comparative negligence State, the fact finder (again the judge or jury) may decide the relative responsibility of each party to the litigation, and then make an allocation of liability to each such party. For example, if Billy was found to be $20 \%$ at fault, his recovery could be as high as $80 \%$.

2. Is the recreation council of New Windsor liable?

It may be, however, as a non-profit they would arguably have no assets with which to satisfy a monetary judgment. Unless however, they had an insurance policy which would provide coverage, but only up to and including any policy limits. The league, coach, field owner and Board of Directors would most likely be covered by the policy as well. But again, only up to the policy limits. Any excess of monetary damages would need to come from another source.

3. Could Billy's parents collect if the Judge or Jury were to award a 3 million dollar judgment?

Maybe, it depends upon whether or not the State where the accident occurred has a pain and suffering cap. And if so, for how much? At that point, the family could only collect what is allowed by statute. But again, this would only occur in a comparative negligence state. Keeping in mind, that if the accident occurred in a contributory negligence state, the family would collect nothing.

4. Could the County be held liable?

Probably not, if they were to raise the defense of "sovereign immunity". If that is raised successfully, it would mean that the government cannot be sued without their consent, and they were therefore have immunity from a civil lawsuit. This is a concept that was brought to the United States as part of their common law adoption from England, based on the rationale that one could not sue the King for a grievance. 
5. Could the manufacturing company be held liable?

Possibly. Since they are located in another country, service of process (summons service) and jurisdiction (power of the Court to hear the case) could become a problem. The plaintiff's would have to successfully argue the concept of "minimum contacts", in order for the Court to exercise its long arm jurisdiction and bring the company under its power. In addition, the company will reiterate that they provide adequate consumer warnings with all equipment sales of goods and that governing bodies have also established inspection policies, however, they are rarely followed.

It is very likely that the company will argue that once the goal post assembly leaves their control, that they are no longer responsible for another party's potential negligence.

\section{AUTHOR BIOGRAPHY}

Mr. Neil spent six years as the President of the Maryland State Youth Soccer Association. During that time, he had the opportunity to head an organization with over 60,000 registered soccer players. As such, he became familiar with the current issue involving goal post safety and the resulting potential liability.

\section{SUGGESTED LITERATURE}

See attached exhibit "A" http://www.anchoredforsafety.org/incidents.html Various cases taken from www.anchoredforsafety.org amednews.com, July 23, 2012, Alicia Dallegos

Retrieved from, www.schmidtandclark.com

Retrieved from, www.corboydemetrio.com/news

Washington Post, September 10, 2012, Ann E. Marimow

Retrieved from, 5newsonline.com, March 6, 2013, Jocelyne Pruna

Arizona Daily Sun May 3, 2008, pg. A3 (8 year old dies when soccer goal falls)

Chicago Tribune, May 21, 2005, Susan Kuczka

USYOUTHSOCCER.ORG, February 18, 2012, Lori Windolf Crispo, et al. (Liability Claims)

Baltimore Sun, September 18 2012, Ian Duncan

Retrieved from, Maryland Injury Attorney Blog, November20, 2012, Jeff Butschky

Retrieved from, www.cpsc.gov, January 31, 1995, (Guidelines for Movable Soccer Goal Safety)

\section{Applicable courses:}

- Legal Studies

- Sports Law

- Legal Environment

- Business Law 


\section{NOTES}

